\title{
A simplified shear strength evaluation model for reinforced concrete corbels
}

\author{
J. K. Lu ${ }^{1}$, S. Y. Kuo ${ }^{2}$, J. Y. Lin ${ }^{1} \&$ S. H. Hsu ${ }^{3}$ \\ ${ }^{I}$ Department of Civil Engineering, National Pingtung University of \\ Science and Technology, Taiwan ROC \\ ${ }^{2}$ Department of Civil Engineering, De Lin Institute of Technology, \\ Taiwan ROC \\ ${ }^{3}$ New Construction Office, Taipei City Government, Taiwan ROC
}

\begin{abstract}
A shear strength model for reinforced concrete corbels is developed by modifying the softened strut-and-tie model. Using the concept of $\mathrm{Lu}$ and $\mathrm{Wu}$, the constitutive equation is developed. Then, the constitutive equation is combined with the equilibrium equations of Hwang and Lee. The model is used to predict the shear strength of reinforced concrete corbels. The results of the model are compared with the experimental data and the results of ACI code.

Keywords: softened strut-and-tie model, reinforced concrete corbels, shear strength.
\end{abstract}

\section{Introduction}

Corbels are cantilevers having shear span-to-depth ratios not greater than unity, which tend to control by shear as a deep beam, rather than flexural members. Reinforced concrete corbels are becoming a common feature in building construction. Simple design procedures to produce safe and economic corbels are therefore required. Much research is carried into investigation about the shear strength of corbels.

In test, the most common modes of failure of corbels are crushing or splitting of the compression strut. ACI 318-95 [3] used the shear-friction method to calculate the shear capacities of corbels. It is shown that most of the shear capacities of corbels calculated by ACI code are underestimated [4-6]. ACI 318-02 [7] provides the strut-and-tie model as an alternate method to 
calculate the shear capacities of corbels. A softened strut-and-tie model for predicting the shear strengths of reinforced concrete corbels is proposed by Hwang et al [4]. It is based on the strut-and-tie concept with satisfying equilibrium, compatibility and the constitutive law of concrete. Hwang and Lee [2] modified the softened strut-and-tie model to develop a simple predicting procedure. But, the procedure is still complicate.

To further simplify the design procedure, the present paper developed a shear strength model for reinforced concrete corbels. Using the concept of $\mathrm{Lu}$ and $\mathrm{Wu}$ [1], the constitutive equation is developed. Then, the constitutive equation is applied with the equilibrium equations of Hwang and Lee [2]. The results of the present model are compared with the results of ACI code and the experimental data from published papers $[6,8-11]$.

\section{The ACI model}

The design procedure for corbels given by section 11.9 in ACI-02 [7] code is based on the shear-friction method. The shear capacity of the corbel $V_{n}$ is obtained by:

$$
V_{n}=\mu A_{v f} f_{y}
$$

with

$$
V_{n} \leq 0.2 f_{c}^{\prime} b_{w} d
$$

and

$$
V_{n} \leq 5.6 b_{w} d
$$

where $A_{v f}$ represents the area of shear-friction reinforcement; $\mu$ is coefficient of friction; $b_{w}$ is the web width and $d$ is the distance from extreme compression fiber to centroid of tension reinforcement; $f_{y}$ represents the yield strength of reinforcement and $f_{c}^{\prime}$ represents the compressive strength of concrete.

\section{The present model}

In this paper, a simplified shear strength model for reinforced concrete corbels is developed by modifying the softened strut-and-tie model. The constitutive equation is developed by using the concept of $\mathrm{Lu}$ and $\mathrm{Wu}$ [1]. The diagonal compression stress is defined in terms of the yield strength of reinforced steel and the compression strength of concrete. Then, the constitutive equation is combined with the equilibrium equations of Hwang and Lee [2]. 


\subsection{Equilibrium equations}

The force equilibrium of a diagonal compression using a strut-and-tie perspective is shown in figure 1 .

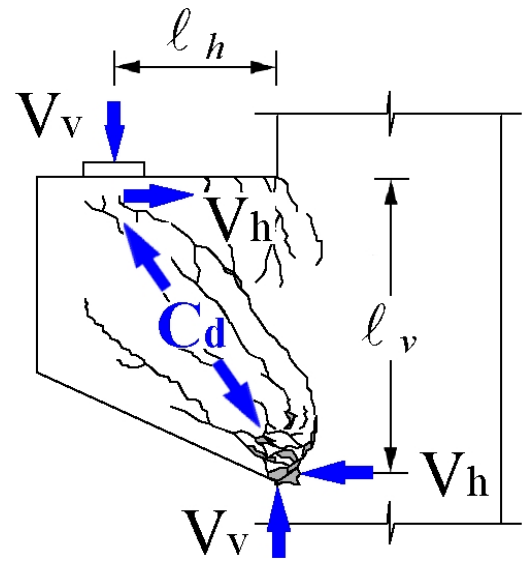

(a)

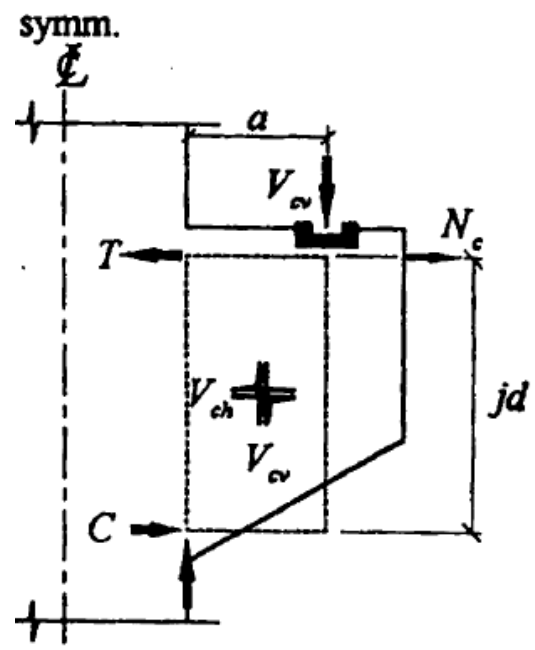

(b) (Hwang et al [4])

Figure 1: $\quad$ The softened strut-and-tie model of corbel. 
The vertical shear force $\mathrm{V}_{\mathrm{V}}$ can be obtained by:

$$
V_{v}=C_{d} \sin \theta
$$

where $C_{d}$ represents the diagonal compression and the $\theta$ denotes the angle of inclination of the diagonal with respect to the compression horizontal axis. Also, the horizontal shear force $\mathrm{V}_{\mathrm{h}}$ can be obtained by:

$$
V_{h}=C_{d} \cos \theta
$$

By using the equation (4) and (5), following relationship can be obtained by:

$$
\frac{V_{v}}{V_{h}}=\frac{\ell_{v}}{\ell_{h}}=\tan \theta
$$

Then, the angle of inclination $\theta$ can be obtained:

$$
\theta=\tan ^{-1}\left(\frac{\ell_{v}}{\ell_{h}}\right)
$$

where $l_{V}$ and $l_{h}$ represent the internal level arms of the vertical and horizontal shear couples, respectively. According to linear bending theory, the $l_{\mathrm{V}}$ and $\mathrm{l}_{\mathrm{h}}$ can be obtained as:

$$
l_{h}=a
$$

and

$$
l_{v}=j d
$$

with the lever arm jd can be estimated as:

$$
j d=d-\frac{k d}{3}
$$

where $a$ presents the shear span and the $\mathrm{kd}$ represents the depth of the compression zone at the section with the coefficient $\mathrm{k}$. 
The coefficient $\mathrm{k}$ is chosen as 0.375 [12] in this paper. Equation (10) can be expressed as:

$$
j d=0.875 d
$$

Substituting equations (8) and (11) into equation (7), we obtain

$$
\theta=\tan ^{-1}\left(\frac{0.875 d}{a}\right)
$$

\subsection{Constitutive laws}

The constitutive equation of concrete used by Hwang and Lee [2] is:

$$
C_{d}=K \zeta f_{c}^{\prime} A_{s t r}
$$

where $\mathrm{K}$ is the strut-and-tie index, $\zeta$ denotes softening coefficient, $A_{\text {str }}$ is the effective area of the diagonal strut. Equation (13) is first suggested by Zhang and Jirsa [13].

The effective area of the diagonal strut $A_{\text {str }}$ used by Hwang and Lee [2] is:

$$
A_{s t r}=a_{s} b_{s}
$$

with

$$
a_{s}=k d
$$

where $a_{s}$ represents the depth of the diagonal strut, $\mathrm{b}_{\mathrm{S}}$ represents the width of the diagonal strut which can be taken as width of the corbel.

The coefficient $\mathrm{k}$ is chosen as 0.375 [12] in this paper. Equation (15) can be expressed as:

$$
a_{s}=0.375 d
$$

Substituting equation (17) into equation (15), we obtain:

$$
A_{\text {str }}=0.375 \mathrm{db}
$$

Instead of equation (13), the compression strength $C_{d}$ is redefined in present paper as:

$$
C_{d}=\sigma_{d} A_{s t r}
$$


where $\sigma_{\mathrm{d}}$ represents the diagonal compression stress. In this paper, the diagonal compression stress $\sigma_{\mathrm{d}}$ is defined in terms of the yield strength of reinforced steel and the compression strength of concrete.

Based on the concept of $\mathrm{Lu}$ and $\mathrm{Wu}[1]$, the $\sigma_{\mathrm{d}}$ is defined by this paper as:

$$
\sigma_{\mathrm{d}}=\mathrm{f}_{1}\left(\rho_{\mathrm{h}}, \mathrm{f}_{\mathrm{yh}}\right)+\mathrm{f}_{2}\left(\mathrm{f}_{\mathrm{c}}^{\prime}\right)
$$

where $\rho_{h}$ represents the ratio of horizontal reinforced steel and $f_{y h}$ represents the yield strength of horizontal reinforced steel. The first terms of equation (18), $f_{1}\left(\rho_{h}, f_{y h}\right)$ present the effect of reinforced steel and the second term, $f_{2}\left(f^{\prime}{ }_{c}\right)$ presents the effect of the compressive strength of concrete.

In this paper, $f_{1}\left(\rho_{h}, f_{y h}\right)$ and $f_{2}\left(f^{\prime}{ }_{c}\right)$ are determined by fitting the proposed model to the experimental data of Foster, Powell and Selim [9]. It is based on that the average of ratio of the calculated shear strength $V_{v}$ to experimental result $\mathrm{V}_{\mathrm{t}}$ is 1.00 . There are:

$$
\mathrm{f}_{1}\left(\rho_{\mathrm{h}}, \mathrm{f}_{\mathrm{yh}}\right)=0.59 \rho_{\mathrm{h}} \mathrm{f}_{\mathrm{yh}}
$$

and

$$
\mathrm{f}_{2}\left(\mathrm{f}_{\mathrm{c}}^{\prime}\right)=0.53 \mathrm{f}_{\mathrm{c}}^{\prime}-0.00143\left(\mathrm{f}_{\mathrm{c}}^{\prime}\right)^{2}
$$

with $f_{c}^{\prime}$ in MPa. Then, equation (19) can be expressed as:

$$
\sigma_{\mathrm{d}}=0.59 \rho_{\mathrm{h}} \mathrm{f}_{\mathrm{yh}}+0.53 \mathrm{f}_{\mathrm{c}}^{\prime}-0.00143\left(\mathrm{f}_{\mathrm{c}}^{\prime}\right)^{2}
$$

\section{The procedure of numerical calculation}

The procedure of determining the shear force corresponding to the reinforced concrete corbels is now further described. In this application, the $a, \mathrm{~b}_{\mathrm{s}}, \mathrm{d}, \rho_{v}$, $\rho_{h}, f_{c}^{\prime}, f_{y v}$ and $f_{y h}$ are known. The procedure of the calculation for the shear force case is shown in figure 2 and described as follows:

Step 1. Calculate $\mathrm{A}_{\text {str }}$ by use of equation (18), $A_{s t r}=0.375 \mathrm{~d} b_{s}$

Step 2. Calculate $\theta$ by use of equation (12),

$$
\theta=\tan ^{-1}\left(\frac{0.875 d}{a}\right)
$$


Step 3. Calculate $\sigma_{\mathrm{d}}$ by use of equation (22),

$$
\sigma_{\mathrm{d}}=0.59 \rho_{\mathrm{h}} \mathrm{f}_{\mathrm{yh}}+0.53 \mathrm{f}_{\mathrm{c}}^{\prime}-0.00143\left(\mathrm{f}_{\mathrm{c}}^{\prime}\right)^{2}
$$

Step 4. Calculate $\mathrm{C}_{\mathrm{d}}$ by use of equation (14), $C_{d}=\sigma_{d} A_{s t r}$

Step 5. Calculate $\mathrm{V}_{\mathrm{V}}$ by use of equation (4), $V_{v}=C_{d} \sin \theta$
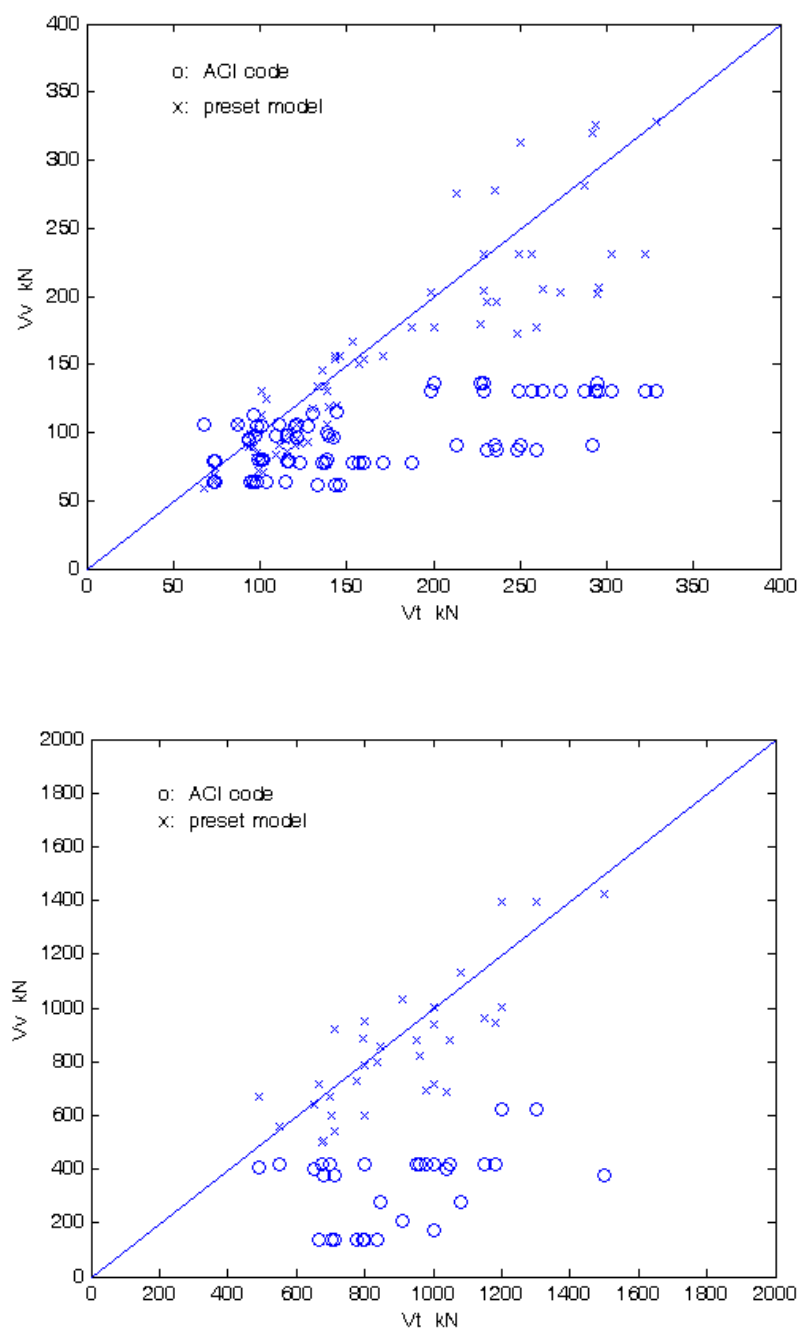

Figure 2: Comparison of the theoretical results with experimental data. 


\section{Comparison of theoretical and experimental results}

A total of 105 experimental data from the literature are used to compare with the present model. The experimental data are from Foster et al [9], Lin [11], Fattuhi and Hughes [8], Yong and Balaguru [6], and Fattuhi [10]. The calculated shear strength of present model and ACI code $\mathrm{V}_{\mathrm{v}}$ are compared with the experimental results $\mathrm{V}_{\mathrm{t}}$. Figure 2(a) shows the theoretical results and the experimental data of Lin [11], Fattuhi and Hughes [8], and Fattuhi [10]. Figure 2(b) shows the theoretical results and the experimental data of Foster et al [9] and Yong and Balaguru [6]. It is seen that the ACI code are under estimate and the present model is quite satisfactory.

Table 1: $\quad$ The theoretical results and experimental data.

\begin{tabular}{|c|c|c|c|c|}
\hline \multirow[t]{2}{*}{ Author } & \multirow{2}{*}{$\begin{array}{r}\text { Number of } \\
\text { specimen }\end{array}$} & & \multicolumn{2}{|r|}{$\frac{V_{v}}{V_{t}}$} \\
\hline & & & ACI code & $\begin{array}{r}\text { Present } \\
\text { model }\end{array}$ \\
\hline \multirow{2}{*}{ Foster et al [9] } & \multirow{2}{*}{22} & AVG & 0.52 & 1.00 \\
\hline & & $\mathrm{COV}$ & 0.31 & 0.23 \\
\hline \multirow{2}{*}{$\operatorname{Lin}[11]$} & \multirow{2}{*}{24} & $\mathrm{AVG}$ & 0.46 & 0.90 \\
\hline & & $\mathrm{COV}$ & 0.22 & 0.20 \\
\hline \multirow{2}{*}{ Ali and White [5] } & \multirow{2}{*}{11} & AVG & 0.48 & 1.02 \\
\hline & & $\mathrm{COV}$ & 0.12 & 0.07 \\
\hline \multirow{2}{*}{ Yong and Balaguru [6] } & \multirow{2}{*}{11} & AVG & 0.21 & 1.05 \\
\hline & & $\mathrm{COV}$ & 0.23 & 0.12 \\
\hline \multirow{2}{*}{ Fattuhi and Hughes [8] } & \multirow{2}{*}{37} & AVG & 0.84 & 0.87 \\
\hline & & $\mathrm{COV}$ & 0.20 & 0.18 \\
\hline \multirow[t]{2}{*}{ Total } & \multirow{2}{*}{105} & $\mathrm{AVG}$ & 0.580 & 0.917 \\
\hline & & $\mathrm{COV}$ & 0.457 & 0.180 \\
\hline
\end{tabular}

The average (AVG) and the coefficient of variation $(\mathrm{COV})$ of the ratio of the calculated shear strength $V_{v}$ to experimental result $V_{t}$ is calculated and shown in table 1. It is noted that the AVG of the present model and ACI code, with respected to total experimental data, are 0.917 and 0.580 , respectively. It is shown that the shear strength calculated from present model is closer to the experimental data than the shear strength calculated from ACI code. The COV of present model and ACI code are 0.180 and 0.457 , respectively. It is shown that the calculated results from present model are more stable than the results from ACI code. 


\section{Concluding remarks}

In this paper, a shear strength model for reinforced concrete corbels is developed by modifying the softened strut-and-tie model. Using the concept of $\mathrm{Lu}$ and $\mathrm{Wu}$ [1], the constitutive equation is developed. Then, the constitutive equation is combined with the equilibrium equations of Hwang, and Lee [2]. Present model are used to predict the shear strength of reinforced concrete corbel. The results of present model are compared with the experimental data and the results of ACI code. It is seen that present model are compares quite well.

\section{Acknowledgement}

The authors would like to thank the financial support provided by the National Science Council, Taiwan.

\section{References}

[1] Lu, J.K., \& Wu, W.H., The application of soften truss model with plastic approach for reinforced concrete beams, Structural Engineering and Mechanics, An International Journal, 11(4), pp. 393-406, 2001.

[2] Hwang, S.J., \& Lee, H.J., Strength prediction for discontinuity regions by softened strut-and-tie model, Journal of Structural Engineering, ASCE, 128(12), pp. 1519-1526, 2002.

[3] ACI Committee 318, Building Code Requirements for Structural Concrete (ACI 318-95) and Commentary (ACI 318R-95), American Concrete Institute, Farmington Hills, Michigan, USA, 1995.

[4] Hwang, S.J., Lu, W.Y., \& Lee, H.J., Shear strength prediction for reinforced concrete corbels, ACI Structural Journal, 97(4), pp. 543-552, 2000 .

[5] Ali, M. A. \& White, R. N., Consideration of compression stress bulging and strut degradation in truss modeling of ductile and brittle corbels, Engineering Structures, 23, pp. 240-249, 2001.

[6] Yong, Y. K. \& Balaguru, P., Behavior of reinforced high-strengthconcrete corbels, Journal of Structural Engineering, ASCE, 120(4), pp. 1182-1201, 1994.

[7] ACI Committee 318, Building Code Requirements for Structural Concrete (ACI 318-02) and Commentary (ACI 318R-02), American Concrete Institute, Farmington Hills, Michigan, USA, 2002.

[8] Fattuhi, N.I., \& Hughes, B.P., Ductility of reinforced concrete corbels containing either steel fibers or stirrups, ACI Structural Journal, 86(6), pp. 644-651, 1989.

[9] Foster, S.J., Powell, R.E., \& Selim, H.S., Performance of high-strength concrete corbels, ACI Structural Journal, 93(5), pp. 555-563, 1996.

[10] Fattuhi, N.I., Strength of FRP corbels in flexure, Journal of Structural Engineering, ASCE, 120(2), pp. 360-377, 1994. 
546 Computational Methods and Experimental Measurements XIII

[11] Lin, R.-D., Behavior of Reinforced Concrete Corbels, Master thesis, Department of construction engineering, National Taiwan University of Science and Technology, Taiwan, 2002.

[12] Nilson, A.H., Design of Concrete Structure. $11^{\text {th }}$ Ed, McGraw-Hill, NY, USA, pp. 146, 1997.

[13] Zhang, L. \& Jirsa, J. O., A study of shear behavior of reinforced concrete beam-column joints, PMFSEL Rep. No. 82-1, Department of Civil Engineering, University of Texas, Austin, TX, USA, 1982. 